\title{
Blood pressure and renal hemodynamic effects of angiotensin fragments
}

\author{
Rui Yang ${ }^{1,2}$, Ilse Smolders ${ }^{2}$ and Alain G Dupont ${ }^{1}$ \\ Angiotensin (Ang) II, the main effector peptide of the renin-Ang system, increases arterial blood pressure through Ang II \\ type $1 \mathrm{~A}\left(\mathrm{AT}_{1 \mathrm{a}}\right)$ receptor-dependent arterial vasoconstriction and by decreasing renal salt and water excretion through extrarenal \\ and intrarenal mechanisms. $\mathrm{AT}_{2}$ receptors are assumed to oppose these responses mediated by $\mathrm{AT}_{1}$ receptors, thereby \\ attenuating the pressor effects of Ang II. Nevertheless, a possible role of $\mathrm{AT}_{2}$ receptors in the regulation of renal hemodynamics \\ and sodium homeostasis remains to be unclear. Several other Ang fragments such as Ang III, Ang IV, Ang-(1-7) and Ang A \\ have also been shown to display biological activity. In this review, we focus on the effects of these Ang on blood pressure, \\ renal hemodynamics and sodium water handling, and discuss the receptors involved in these actions. \\ Hypertension Research (2011) 34, 674-683; doi:10.1038/hr.2011.24; published online 17 March 2011
}

Keywords: angiotensin fragments; blood pressure; kidney; renal hemodynamics

\section{INTRODUCTION}

The renin-angiotensin (Ang) system (RAS) plays a central role in the control of arterial blood pressure and sodium water homeostasis. Renin, a proteolytic enzyme secreted by the juxtaglomerular apparatus of the kidney, cleaves angiotensinogen at the $\mathrm{N}$ terminus to form the decapeptide, Ang I. The latter has no appreciable biological activity, but is converted by the dipeptidyl carboxypeptidase, Ang-converting enzyme (ACE), to the octapeptide Ang II (Asp-Arg-Val-Tyr-IleHis-Pro-Phe) ${ }^{1-3}$ (Figure 1). ACE is a membrane-bound enzyme on the surface of endothelial cells and is particularly abundant in the lung. ACE also inactivates bradykinin and a number of other peptides. Ang II, the main effector peptide of the RAS, is degraded by aminopeptidases A and $\mathrm{N}$ to Ang III and Ang IV, respectively (Figure 1). These metabolites have long been considered of little importance, but are now known to exert biological activity. ${ }^{4-6}$ This is also the case for other Ang fragments: the heptapeptide Ang-(1-7), which is processed from Ang I by tissue endopeptidases, ${ }^{7}$ and the octapeptide Ang A, which is generated from Ang II by enzymatic decarboxylation of Asp. ${ }^{1,8}$

The RAS was originally regarded as a circulating system; however, the existence of 'local' or 'tissue' RAS has been identified in most organs. ${ }^{9}$ ACE is indeed also present in other vascular tissues and organs, including the heart, brain and kidney. Therefore, Ang II can be formed locally in different vascular beds and can exert biological effects independent of blood-borne Ang II. In the kidney, most of the intrarenal Ang II is locally generated, rather than derived from circulating Ang I or Ang II. ${ }^{10,11}$ Ang II and Ang III concentrations in renal interstitial fluid are roughly 1000-fold higher than that in the plasma. $^{12}$
In this review, we focus on the effects of different Ang peptides on blood pressure, renal hemodynamics and sodium excretion, and discuss the receptors involved in these effects (Table 1).

\section{ANGIOTENSIN II}

$\mathrm{AT}_{1}$ and $\mathrm{AT}_{2}$ receptors

The biological functions of Ang II are mediated by at least two pharmacologically distinct receptors, the Ang II type $1\left(\mathrm{AT}_{1}\right)$ and Ang II type $2\left(\mathrm{AT}_{2}\right)$ receptors (Figure 2$){ }^{13}$ Both are seven-transmembrane glycoproteins (G-protein-coupled receptors) with $30 \%$ sequence similarity, ${ }^{13,14}$ and both are expressed in the kidney. ${ }^{15-18}$

$\mathrm{AT}_{1}$ receptors are abundantly expressed in cells of the renal glomeruli, tubules, vasculature and interstitial space. ${ }^{18}$ In rodents, two subtypes of the $\mathrm{AT}_{1}$ receptor have been identified, $\mathrm{AT}_{1 \mathrm{a}}$ and $\mathrm{AT}_{1 \mathrm{~b}}$ receptors, ${ }^{19}$ which share $95 \%$ sequence homology and exhibit similar ligand binding affinities and signal-transduction properties, but differ in their tissue expression. In the kidney, $\mathrm{AT}_{1 \mathrm{a}} \mathrm{mRNA}$ is present in mesangial and juxtaglomerular cells, proximal tubules, vasa recta and interstitial cells, whereas $\mathrm{AT}_{1 \mathrm{~b}}$ mRNA is found only in mesangial and juxtaglomerular cells, and in the renal pelvis. $\mathrm{AT}_{1 \mathrm{a}}$ receptors are more abundant in the kidney than $\mathrm{AT}_{1 \mathrm{~b}} \cdot{ }^{20} \mathrm{AT}_{1 \mathrm{a}}$ receptors are also expressed in the liver, adrenal gland, ovary, heart, aorta, lung, testis, brain, adipose tissue and vascular smooth muscle, whereas $\mathrm{AT}_{1 \mathrm{~b}}$ receptors are confined to the adrenal gland, brain and testis. ${ }^{21}$

$\mathrm{AT}_{2}$ receptors are highly expressed during fetal development and in newborn mammalian kidneys, with very little expression in the adult mammalian kidney. ${ }^{22}$ This has led to the suggestion that $\mathrm{AT}_{2}$ receptors may be involved in development, differentiation and/or growth. ${ }^{23-25}$ In the adult kidney, $\mathrm{AT}_{2}$ receptors are mainly localized in the

${ }^{1}$ Department of Pharmacology, Brussels, Belgium and ${ }^{2}$ Department of Pharmaceutical Chemistry, Drug Analysis and Drug Information, Vrije Universiteit Brussel, Brussels, Belgium

Correspondence: Dr AG Dupont, Department of Pharmacology, Vrije Universiteit Brussel, Laarbeeklaan 103, 1090 Brussels, Belgium.

E-mail: alain.dupont@uzbrussel.be

Received 25 August 2010; revised 10 January 2011; accepted 25 January 2011; published online 17 March 2011 


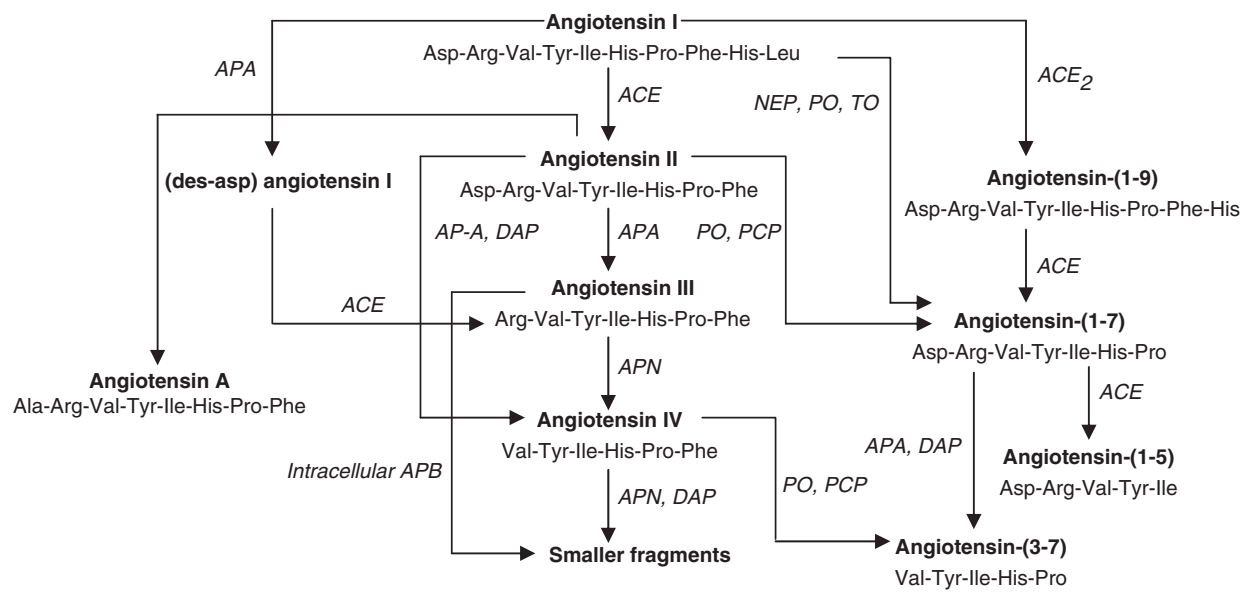

Figure 1 Overview of the chemical structures and the enzymes involved in the synthesis of Ang II and its different fragments. ACE, angiotensin-converting enzyme; $\mathrm{ACE}_{2}$, human angiotensin-converting enzyme homologue; Ang, angiotensin; APA, APB, APN, aminopeptidase A, B and N; DAP, dipeptidyl aminopeptidases; PO, propyl oligopeptidase; PCP, carboxypeptidase; NEP, neprilysin; TO, thimet oligopeptidase.

Table 1 Main effects of Ang fragments in different animal models

\begin{tabular}{|c|c|c|c|}
\hline & Rodents & Dogs & Human \\
\hline Ang II & $\begin{array}{l}\mathrm{AT}_{1} \text { receptor-mediated increased } \mathrm{BP}, \mathrm{RVR} \text {, decreased RBF; } \\
\text { increased aldosterone secretion and increased sodium } \\
\text { reabsorption } \\
\mathrm{AT}_{2} \text { receptor-mediated vasodilation and hypotensive effect } \\
\text { (conflicting results) } \\
\mathrm{AT}_{2} \text { receptor-mediated natriuresis }\end{array}$ & $\begin{array}{l}\text { Sodium retention at low doses and } \\
\text { pressure natriuresis at high doses }\end{array}$ & $\begin{array}{l}\mathrm{AT}_{1} \text { receptor-mediated increased } \mathrm{BP} \text {, } \\
\mathrm{RVR} \text {, decreased } \mathrm{RBF} \text {; increased } \\
\text { aldosterone secretion and increased } \\
\text { sodium reabsorption } \\
\mathrm{AT}_{2} \text { receptor-mediated vasodilation } \\
\text { (few studies) }\end{array}$ \\
\hline Ang III & $\begin{array}{l}A T_{1} \text { receptor-mediated increased } B P, R V R \text {, decreased } \\
R B F \text {; increased aldosterone secretion } \\
A T_{2} \text { receptor-mediated natriuresis (SHR) }\end{array}$ & Increased aldosterone secretion & Increased aldosterone secretion \\
\hline Ang IV & $\begin{array}{l}\mathrm{AT}_{4} \text { receptor-mediated increased } \mathrm{RBF} \text { in some studies } \\
\text { (not confirmed by others) } \\
\mathrm{AT}_{1} \text { receptor dependent increased } \mathrm{BP}, \mathrm{RVR} \text {, decreased } \\
\mathrm{RBF}\end{array}$ & $\begin{array}{l}\text { No effect on } \mathrm{BP} \text {, sodium excretion or } \\
\text { aldosterone secretion }\end{array}$ & $\begin{array}{l}\text { No effect on BP, sodium excretion } \\
\text { or aldosterone secretion }\end{array}$ \\
\hline Ang-(1-7) & $\begin{array}{l}\text { Mas receptor-mediated decreased BP } \\
\text { Conflicting data on effects renal hemodynamics and } \\
\text { sodium excretion }\end{array}$ & $\begin{array}{l}\text { No effect on BP, sodium excretion or } \\
\text { aldosterone secretion (increased sodium } \\
\text { excretion in another study) }\end{array}$ & $\begin{array}{l}\text { No effect on BP, sodium excretion } \\
\text { or aldosterone secretion }\end{array}$ \\
\hline Ang A & $\mathrm{AT}_{1}$ receptor-mediated increased $\mathrm{BP}, \mathrm{RVR}$, decreased $\mathrm{RBF}$; & & \\
\hline
\end{tabular}

Abbreviations: Ang, angiotensin; $\mathrm{AT}_{1}$, Ang II type $1 \mathrm{~A}$; BP, blood pressure; RBF, renal blood flow; RVR, renal vascular resistance; SHR, spontaneously hypertensive rats.

glomerular mesangial cells $s^{22,26,27}$ or the adventitia of the preglomerular arcuate and interlobular arteries. ${ }^{28} \mathrm{AT}_{2}$ receptors are upregulated in the adult kidney in response to sodium depletion ${ }^{27}$ or kidney damage $^{29}$ in obese Zucker rats $^{30}$ and spontaneously hypertensive rats (SHRs). ${ }^{31}$ In other pathological conditions, such as stroke, an increased $\mathrm{AT}_{2}$ receptor gene expression in the infarcted cortex was reported. ${ }^{32}$

Few studies have investigated the functional expression of $\mathrm{AT}_{2}$ receptors in human beings. They are expressed in human skin ${ }^{33,34}$ and in the coronary circulation. ${ }^{35}$ In the adult human renal cortex, $\mathrm{AT}_{2}$ receptor mRNA is mainly expressed in interlobular arteries. ${ }^{36}$

\section{Effects of Ang II on blood pressure and sodium-volume} homeostasis

Ang II increases arterial pressure via two principal effects. The first, vasoconstriction, occurs very rapidly, within seconds, and very intensely in the arterioles and to a considerably lesser extent in the veins. The second is the effect on the kidneys to decrease the excretion of both salt and water. This increases the extracellular fluid volume, which then increases arterial pressure slowly over a period of hours and days. This long-term effect, acting through the extracellular fluid volume mechanism, is even more powerful than the acute vasoconstrictor mechanism in increasing blood pressure.

Ang II causes the kidneys to retain salt and water through extrarenal and intrarenal mechanisms. ${ }^{37}$ Ang II increases sympathetic nerve stimulation, which increases renal tubular sodium reabsorption directly or indirectly through renal vasoconstriction. Moreover, Ang II stimulates the synthesis and secretion of aldosterone from the adrenal cortex, and aldosterone in turn increases salt and water reabsorption by the distal tubule. ${ }^{38,39}$ Within the kidney, Ang II increases predominantly proximal tubular sodium reabsorption. It also induces renal microvascular constriction, in particular of the 


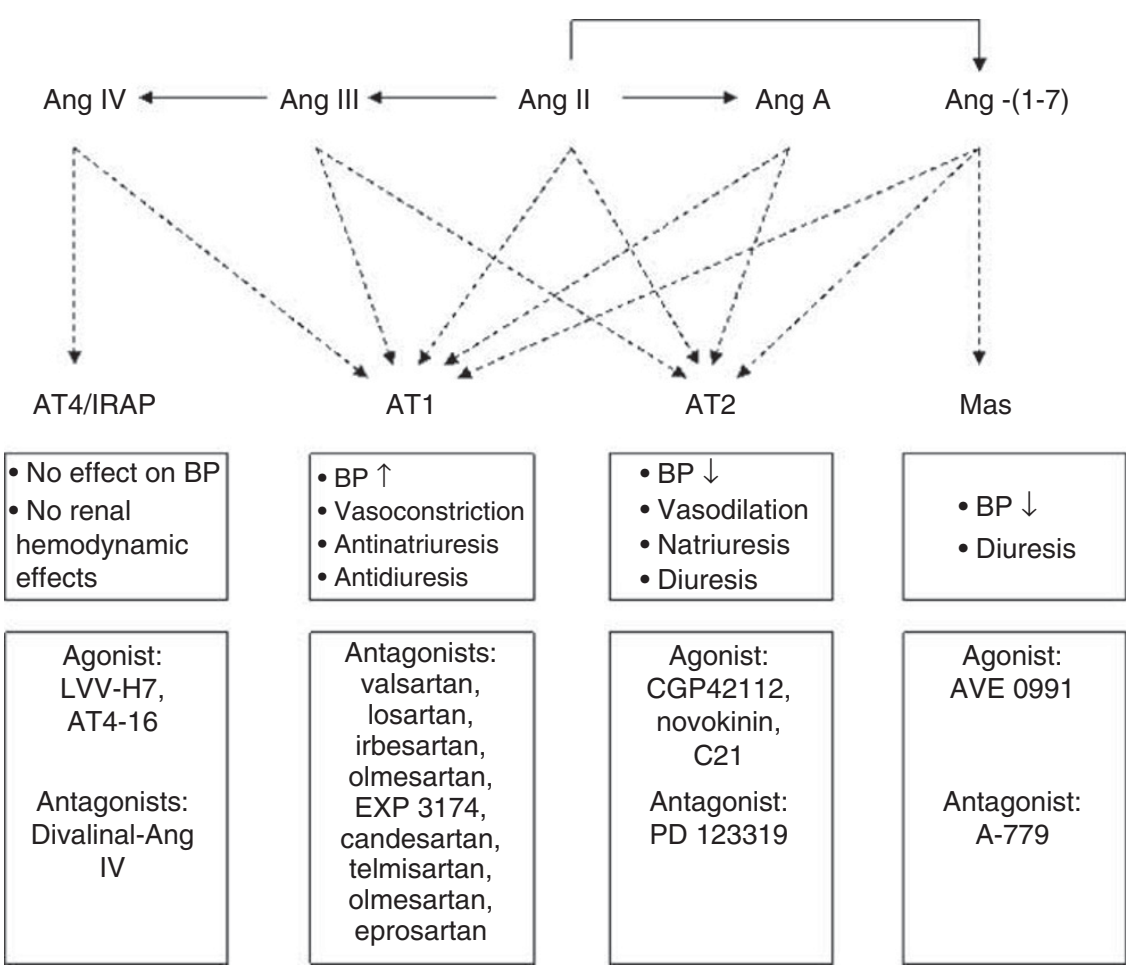

Figure 2 Angiotensin fragments and their actions on the different receptors.

efferent arterioles. This helps maintaining the glomerular filtration rate and tends to increase sodium reabsorption by altering peritubular capillary physical forces. ${ }^{40}$

During hypovolemia (for example, hemorrhagic shock) and in sodium-deficient states, intrarenal Ang II levels are elevated and, in turn, increase both renal sodium and water reabsorption, thereby playing an important physiological role in maintaining circulating volume and blood pressure. ${ }^{37,41}$

\section{$\mathrm{AT}_{1}$ receptor-mediated blood pressure effects of Ang II}

The role of Ang II in the regulation of blood pressure has been extensively investigated using different animal models. In anesthetized rats, systemic (intravenous, i.v.) or local (intrarenal, i.r.) administration of Ang II led to pressor effects, which could be blocked by $\mathrm{AT}_{1}$ receptor antagonists. ${ }^{13,42-45}$ Gene-targeting studies further pointed out that these effects are mainly mediated by $\mathrm{AT}_{1 \mathrm{a}}$ receptors. ${ }^{46,47}$ Knock out $(-/-)$ of the $A T_{1 a}$ receptor gene decreased baseline blood pressure ${ }^{46,48}$ and abolished the pressor response to Ang II infusion, ${ }^{46,49}$ whereas deletion of $A T_{1 b}$ genes did not alter baseline blood pressure, nor the pressor response to Ang II. ${ }^{46,50}$ Ang II induced dose-dependent increases in blood pressure in $\mathrm{AT}_{1 \mathrm{a}}(-/-)$ mice pretreated with an ACE inhibitor, which were inhibited by $\mathrm{AT}_{1}$ receptor blockade. ${ }^{51}$ Therefore, the $\mathrm{AT}_{1 \mathrm{~b}}$ receptor may contribute to the cardiovascular effects of Ang II in the absence of the $\mathrm{AT}_{1 \mathrm{a}}$ receptor, and presumably is subsidiary to the major $\mathrm{AT}_{1 \mathrm{a}}$ subtype in normal animals. This notion is supported by data obtained in mice with a double $\mathrm{AT}_{1 \mathrm{a}}(-/-)$ and $\mathrm{AT}_{1 \mathrm{~b}}(-/-)$, which have a more severe phenotype with a significant lower body weight, kidney weight, blood pressure and heart rate than mice lacking only the $\mathrm{AT}_{1 \mathrm{a}}$ receptor. ${ }^{46,52}$

$\mathrm{AT}_{1}$ receptors are expressed in many organ systems, including the circulatory system, the central nervous system and the urinary system, and so on, ${ }^{53}$ which are presumed to play key functions in blood pressure homeostasis. Interestingly, a cross-transplantation study between genetically matched $\mathrm{AT}_{1}(-/-)$ and wild-type mice revealed that, for the development of Ang II-induced hypertension and cardiac hypertrophy, renal $\mathrm{AT}_{1}$ receptors are required. ${ }^{54}$

In man, Ang II also exerts vasoconstriction, sodium retention and aldosterone secretion through $\mathrm{AT}_{1}$ receptor stimulation, and drugs inhibiting Ang II formation or selectively blocking the $\mathrm{AT}_{1}$ receptor are highly effective antihypertensive agents. ${ }^{55,56}$

\section{$\mathrm{AT}_{1}$ receptor-mediated renal effects of Ang II}

Systemic administration ${ }^{57}$ and i.r. administration ${ }^{58-61}$ of Ang II produced dose-dependent decreases in total renal blood flow (RBF) and renal cortical blood flow (CBF), and increases in renal vascular resistance and renal cortical vascular resistance, which were blocked by $\mathrm{AT}_{1}$ receptor antagonists. ${ }^{47,62}$ Within the microvasculature, Ang II constricted both the afferent and efferent arterioles, ${ }^{63,64}$ although the efferent arterioles are much more sensitive. ${ }^{40}$ Blockade of the $\mathrm{AT}_{1}$ receptor elicited increases in RBF, indicating a role of Ang II in maintaining renal vascular tone. ${ }^{57}$

I.r. infusion of Ang II in dogs at rates chosen to increase renal arterial concentration by only $10-15 \mathrm{pg} \mathrm{ml}$, a level that is still within the physiological concentrations of Ang II, markedly reduced sodium excretion, ${ }^{40}$ indicating that physiological levels of Ang II are capable of inducing antinatriuretic effects. Olsen et al. ${ }^{65}$ compared the responses with various rates of Ang II infusion in normal dogs in which renal perfusion pressure was permitted to increase and in the same dogs when renal arterial pressure was servo-controlled during Ang II infusion. These experiments showed that, in normal dogs, low doses (5-45 $\mathrm{ng} \mathrm{kg}^{-1} \mathrm{~min}^{-1}$, i.v.) of Ang II decreased sodium excretion, whereas infusion rates of $135-1215 \mathrm{ng} \mathrm{kg}^{-1} \mathrm{~min}^{-1}$ i.v. caused natriuresis and diuresis related to the increase in blood pressure. This phenomenon is commonly referred to as 'pressure natriuresis. ${ }^{66-69}$ In contrast, when renal arterial pressure was servo-controlled, Ang II 
infusion at all infusion rates $\left(5-1215 \mathrm{ng} \mathrm{kg}^{-1} \mathrm{~min}^{-1}\right.$, i.v. $)$ in the same dogs decreased urinary sodium excretion. ${ }^{65}$ Therefore, in animal experiments, depending on the dose of the Ang II as well as the magnitude of the blood pressure responses, both antinatriuresis and natriuresis can occur. Consistent with this notion, micropuncture and microperfusion studies showed that Ang II modulated proximal tubular sodium reabsorption effects in a dose-dependent and biphasic manner ${ }^{70-73}$ through apical sodium channels. ${ }^{74}$ The physiological significance of this pressure natriuresis is uncertain, although it is probably involved in certain pathological conditions such as malignant hypertension. ${ }^{40}$

\section{$\mathrm{AT}_{2}$ receptor-mediated renal and blood pressure effects of Ang II?}

The function of the $\mathrm{AT}_{2}$ receptor is less well understood, possibly because the $\mathrm{AT}_{2}$ receptor has a low degree of expression compared with that of the $\mathrm{AT}_{1}$ receptor. In general, it is assumed that $\mathrm{AT}_{2}$ receptors oppose the responses mediated by $\mathrm{AT}_{1}$ receptors. ${ }^{35,75,76}$ Although the $\mathrm{AT}_{1}$ receptor is involved in pressor, vasoconstrictor and antinatriuretic effects, the $\mathrm{AT}_{2}$ receptor appears to mediate depressor effects, vasodilation and natriuresis. ${ }^{77,78} \mathrm{AT}_{2}$ receptor stimulation could increase the production of NO and cGMP either by increasing bradykinin production and bradykinin $\mathrm{B} 2$ receptor stimulation or by direct activation of $\mathrm{NO}$ production. ${ }^{79} \mathrm{AT}_{2}$ receptormediated vasodilation has been shown in small resistance arteries of the mesenteric, uterine, adrenal, coronary and peripheral circulations in a wide variety of animal models and, in human beings, in large capacitance vessels such as the aorta and in the fetal circulation. ${ }^{79} \mathrm{AT}_{2}$ receptor-mediated vasodilation in the renal vasculature has so far not been shown. $\mathrm{AT}_{2}$ receptors were reported to be upregulated and to contribute to Ang II-induced vasodilation in resistance arteries of hypertensive type 2 diabetes patients treated with $\mathrm{AT}_{1}$ receptor blockers. ${ }^{80} \mathrm{AT}_{2}(-/-)$ mice have elevated basal blood pressure and exaggerated pressor responses to exogenous Ang II as compared with wild-type litter mates, which is line with the hypothesis that $\mathrm{AT}_{2}$ receptors counteract $\mathrm{AT}_{1}$ receptor-mediated responses. ${ }^{46,75,76,81,82}$ Moreover, $\mathrm{AT}_{2}(-/-)$ mice have increased prostaglandin $\mathrm{E} 2$ and prostacyclin levels, suggesting that these vasodilator prostanoids might be important in preventing hypertension in this model. ${ }^{83}$ Alternatively, the enhanced pressor response to Ang II in $\mathrm{AT}_{2}(-/-)$ mice could also be due to the upregulation of $\mathrm{AT}_{1}$ receptors triggered by $\mathrm{AT}_{2}$ receptor deficiency. ${ }^{84,85} \mathrm{AT}_{2}$ receptor-mediated vasodilator and depressor actions of Ang II appear more easily when $\mathrm{AT}_{1}$ receptors are blocked by $\mathrm{AT}_{1}$ receptor antagonists. ${ }^{79,86,87}$ This might be due to the predominance of the $\mathrm{AT}_{1}$ receptor over the $\mathrm{AT}_{2}$ receptor expression in blood vessels. ${ }^{79}$ It was suggested that hypotensive responses to $\mathrm{AT}_{1}$ receptor blockade are mediated, at least in part, by $\mathrm{AT}_{2}$ receptor activation. The vasodilator effects mediated by $\mathrm{AT}_{2}$ receptors are also facilitated when the RAS is activated by dietary $\mathrm{Na}^{+}$restriction, ${ }^{79}$ or when $\mathrm{AT}_{2}$ receptors are upregulated as in $\mathrm{SHR}^{31,86-89}$

$\mathrm{AT}_{2}$ receptor-mediated inhibition of $\mathrm{Na}^{+}$transport in rabbit proximal tubule cells has been shown in an in vitro study. ${ }^{90} \mathrm{AT}_{2}(-/-)$ mice were shown to display antinatriuretic hypersensitivity to exogenous Ang II and a shift to the right (less sensitive) in their pressurenatriuresis curves. ${ }^{82,91}$ Direct renal interstitial microinfusion of a selective $\mathrm{AT}_{1}$ receptor antagonist did not influence systemic hemodynamics and did not induce any hormonal changes, but induced a natriuretic response that was abolished by intrarenal co-infusion of the $\mathrm{AT}_{2}$ receptor antagonist $\mathrm{PD}-123319$ (ref. 92), suggesting that the natriuretic response to $\mathrm{AT}_{1}$ receptor blockade is mediated by $\mathrm{AT}_{2}$ receptor activation.

\section{Effect of Ang II on medullary RBF}

Ang II elicits a paradoxical medullary vasodilatation in normotensive animals, mediated by a secondary activation of vasodilator paracrine agents such as prostaglandins, kinins and NO, rather than to a direct action via $\mathrm{AT}_{2}$ receptors. ${ }^{42,93,94}$ Sarkis et al. ${ }^{95}$ observed a biphasic medullary blood flow following i.v. injection of Ang II in normotensive rats characterized by an initial rapid and short-lasting ( $<1 \mathrm{~min}$ ) decrease (vasoconstrictor component), followed by a marked and longer-lasting ( $>2 \mathrm{~min}$ ) increase ( $\mathrm{AT}_{1}$ receptor-dependent vasodilator component) in medullary blood flow. The vasodilator component was mainly due to the release of prostaglandins and, to a lesser extent, of nitric oxide (NO) and kinins. ${ }^{95}$ In SHR and Lyon genetically hypertensive rats, the vasoconstrictor component was more pronounced, and/or the vasodilator component was attenuated after stimulation with Ang II. ${ }^{95,96}$

\section{ANGIOTENSIN III}

Ang III is generated from Ang II by the enzyme aminopeptidase A (Figure 3), ${ }^{97}$ or from Ang I, which can be converted directly to Ang III by ACE. ${ }^{98}$ Like Ang II, Ang III displays similar affinity for $\mathrm{AT}_{1}$ and $\mathrm{AT}_{2}$ receptors (Figure 2), ${ }^{99}$ but it is more sensitive to aminopeptidase N. ${ }^{100}$

Ang III reduces RBF after systemic administration. ${ }^{101}$ I.v. Ang III or Ang II achieving the same plasma concentrations in conscious dogs had equipotent $\mathrm{AT}_{1}$ receptor-dependent effects on blood pressure and sodium excretion, but the metabolic clearance rate of Ang III was five times that of Ang II. ${ }^{102}$ This study supports earlier conclusions that Ang II is the main effector of the 'circulating RAS'. However, data obtained in SHR point to Ang III as an important effector peptide. Ang III- and Ang II-induced dose-dependent increases in renal perfusion pressure were both enhanced in SHR compared with WKY rats, ${ }^{103}$ but kidneys of SHR displayed higher activity of aminopeptidase A, the principal enzyme that hydrolyzes Ang II to Ang III, ${ }^{104}$ suggesting that Ang III could contribute to the enhanced renal response to Ang II in the SHR. Moreover, Ang III, but not Ang II, induced natriuresis through $\mathrm{AT}_{2}$ receptor activation during $\mathrm{AT}_{1}$ receptor blockade in SHR. ${ }^{92}$ This natriuresis was augmented by the blockade of aminopeptidase $\mathrm{N}$, an enzyme metabolizing Ang III to Ang IV, ${ }^{105}$ suggesting an important role of Ang III in sodium excretion. Further research is required to clarify a possible role of

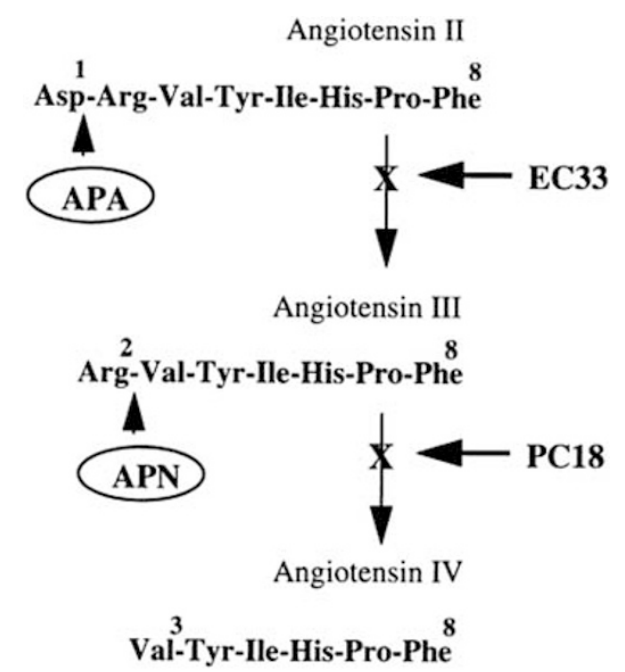

Figure 3 Metabolic conversion of angiotensin (Ang) II, via Ang III-IV. EC33 and $\mathrm{PC} 18$ are selective inhibitors of aminopeptidase A (APA) and aminopeptidase (APN), respectively. 
Ang III in the regulation of the renal hemodynamics and sodium excretion.

Ang III is also a potent stimulator of aldosterone secretion. In the $\mathrm{rat}^{57,106}$ and in anesthetized dogs, ${ }^{107,108}$ infusion of Ang III stimulated aldosterone release similarly to Ang II, although it appeared less potent. On the other hand, in a study in conscious dogs during double blockade of the RAS (combined ACE inhibition and aldosterone receptor blockade), Ang III was significantly more potent than Ang II in increasing aldosterone release ${ }^{55,109}$ and also produced a very potent antinatriuretic effect already at a dose not producing an increase in blood pressure. ${ }^{109}$ In healthy human beings under acute combined ACE inhibition and aldosterone receptor antagonism, Ang III infusion increased blood pressure and markedly elevated plasma aldosterone without affecting renal sodium excretion. These changes were observed in the absence of a measurable increase in Ang immunoreactivity, suggesting that Ang III is more potent than Ang II in stimulating aldosterone secretion. ${ }^{109}$ On the basis of these experiments, these two groups of investigators raised the question of a specific receptor for Ang III, which has so far, however, never been established. ${ }^{55,109}$

\section{ANGIOTENSIN IV}

Ang IV is formed by removing the first $\mathrm{NH}_{2}$-terminal amino acid $\left(\mathrm{Arg}^{2}\right)$ from Ang III by aminopeptidase $\mathrm{N}$ and/or aminopeptidase B (Figure 3). ${ }^{14,110-113}$ Ang IV is then quickly further cleaved into smaller inactive peptide fragments. ${ }^{114}$ Ang IV has low affinity for $\mathrm{AT}_{1}$ and $\mathrm{AT}_{2}$ receptors $\left(\mathrm{EC}_{50}\right.$ within the micromolar range). ${ }^{99,115}$ The plasma clearance of Ang III is substantially higher than that of Ang II. 55,109 Yet, Ang IV displays certain biological effects already at nanomolar concentrations, which are not blocked by $\mathrm{AT}_{1}$ and $\mathrm{AT}_{2}$ receptor antagonists (Figure 2). This, together with the discovery of highaffinity binding sites for $\left[{ }^{125} \mathrm{I}\right]$ Ang IV in the central nervous, vascular and renal systems, ${ }^{16,116,117}$ has led to the concept of a novel Ang receptor subtype: the ' $\mathrm{AT}_{4}$ receptor,' ${ }^{14}$ which was convincingly shown to be 'insulin-regulated aminopeptidase (IRAP)', a membraneanchored zinc-dependent metallopeptidase. ${ }^{118}$

Autoradiographic and radioligand binding experiments have localized $\mathrm{AT}_{4}$ binding sites on microvilli and cell bodies of rat proximal convoluted and straight tubules, ${ }^{17}$ cultured rat mesangial cells, ${ }^{111}$ cultured opossum proximal tubule cells, ${ }^{119}$ apical and basolateral membranes of rabbit cortical tubules, ${ }^{119}$ cultured rabbit ${ }^{120}$ and human collecting duct cells ${ }^{121}$ and cultured human proximal tubule epithelial cells. ${ }^{122}$ In the brain, the $\mathrm{AT}_{4}$ binding sites are prominent in structures important to cognitive processing and sensory and motor functions. ${ }^{123}$ The distribution of $\mathrm{AT}_{4}$ binding sites in the human brain has been shown to be clearly different from that of $\mathrm{AT}_{1}$ receptors. ${ }^{124}$ $\mathrm{AT}_{4}$ binding sites are also present in other peripheral tissues, including vascular smooth muscle cells, bladder, heart, spleen, prostate, adrenal gland and colon. ${ }^{14}$

\section{Blood pressure and renal responses to Ang IV}

In anesthetized rats, i.v. Ang IV infusion at picomolar to nanomolar concentration caused dose-dependent increases in blood pressure, although with less potency than Ang II. This pressor response was completely abolished by $\mathrm{AT}_{1}$ receptor blockade. ${ }^{44,47,62,125}$

Studies on the effects of Ang IV in the kidney have yielded conflicting results. Infusion of Ang IV directly in renal arteries was reported to increase renal $\mathrm{CBF}$ in anesthetized rats as measured by laser Doppler flowmetry, ${ }^{60,126}$ an effect blocked by the specific ' $\mathrm{AT}_{4}$ receptor' antagonist, Divalinal-Ang IV, but not by selective $\mathrm{AT}_{1}$ and $\mathrm{AT}_{2}$ receptor antagonists. L-NAME, an NO synthase inhibitor, also blocked this vasodilator response. ${ }^{60}$ In the same line, studies on the pulmonary and cerebral vasculature also suggested that Ang IV produced an endothelium-dependent vasodilatation associated with increased endothelial NO and cGMP production. ${ }^{127-129}$ In addition, Ang IV was reported to promote the release of vasodilating prostaglandins. ${ }^{130}$ Taken together, the 'AT 4 receptor' was suggested to mediate renal $\mathrm{NO}$ and/or prostaglandin-dependent vasodilation. In contrast, systemic and intrarenal administration of Ang IV reduced $\mathrm{RBF}$ in rats when measured using pulsed Doppler flow probes placed around the renal artery, and this response was prevented by $\mathrm{AT}_{1}$ receptor blockade. ${ }^{44,131,132}$ Infusion of $\mathrm{LVV}-\mathrm{H} 7$, a more stable ligand with a high affinity $\left(K_{\mathrm{i}} \sim 73 \mathrm{~nm}\right)$ for the $\mathrm{AT}_{4}$ receptor, but no affinity for $\mathrm{AT}_{1}$ receptors, ${ }^{133}$ failed to alter $\mathrm{RBF}^{132}$ One study in anesthetized rats reported that intrarenal Ang IV produced an $\mathrm{AT}_{1}$ receptordependent biphasic response with an immediate dose-dependent vasoconstriction, followed by a prolonged vasodilation. ${ }^{59}$

It was suggested that these conflicting results might be explained by differences in the methods used to assess flow and the site of measurement. ${ }^{126}$ Reports of $\mathrm{AT}_{1}$-dependent, Ang IV-induced decreases in flow measured total RBF, whereas the studies that observed increases in flow attributed to IRAP/AT ${ }_{4}$ receptor stimulation, involving laser Doppler methods, which measured superficial CBF. It was argued that Ang IV could induce selective shunting of blood to surface nephrons, ${ }^{134}$ with only small concomitant overall changes in flow. ${ }^{126}$ However, simultaneously monitored RBF and CBF responses after i.v. administration of Ang IV, Ang II and the dopamine receptor agonist fenoldopam showed a high correlation between RBF and $\mathrm{CBF}$ measurements, excluding the above possibility. ${ }^{62}$ Using simultaneous monitoring of RBF and CBF in rats, Ang IV elicited total and cortical renal vasoconstrictor effects after systemic administration through stimulation of $\mathrm{AT}_{1}$ receptors, but with lower potency than Ang II. ${ }^{62}$ Direct intrarenal infusion of Ang IV also induced dosedependent $\mathrm{AT}_{1}$ receptor-mediated pressor and renal vasoconstrictor effects. Ang IV significantly reduced RBF and CBF also when administered intrarenally at subpressor doses. These results are in line with other recent studies showing that Ang IV can induce renal cortical vasoconstrictor effects through $\mathrm{AT}_{1}$ receptor-activated signaling at nanomolar concentrations. ${ }^{44}$ In the same line, $\mathrm{AT}_{1}$ receptor-mediated vasoconstrictor effects of Ang IV were shown in rat renal interlobular arteries and in afferent and efferent arterioles of isolated perfused hydronephrotic kidneys, also at concentrations several fold higher than those required for Ang II. ${ }^{135}$

Our experiments in rats with Ang IV and with more selective ' $\mathrm{AT}_{4}$ ligands', LVV-H7 and AT4-16, did not reveal any putative $\mathrm{AT}_{4} / \mathrm{IRAP}^{-}$ mediated vasodilator response neither after systemic nor after renal administration, and also not after $\mathrm{AT}_{1}$ receptor blockade. ${ }^{62}$

Using transgenic mice, we showed pressor and renal vasoconstrictor responses to Ang IV to be mediated by the $\mathrm{AT}_{1 \mathrm{a}}$ receptor subtype. ${ }^{47}$ The responses were indeed almost completely absent in $\mathrm{AT}_{1 \mathrm{a}}(-/-)$ mice, whereas responses in $\mathrm{AT}_{1 \mathrm{~b}}(-/-)$ mice were comparable to those in corresponding wild-type mice. IRAP/AT 4 receptor $(-/-)$ mice had comparable baseline blood pressure and CBF, and comparable responses to Ang IV as their corresponding wild-type mice, confirming that the putative IRAP/AT 4 receptor is not involved in the pressor and renal hemodynamic effects of Ang IV. ${ }^{47}$

Ang IV has been reported to increase whole kidney urinary sodium and water excretion independent of sympathetic innervation in one study. ${ }^{122}$ In line with this natriuretic effect, Ang IV has been shown to produce a dose-dependent inhibition of tubular sodium reabsorption. ${ }^{17}$ Pretreatment with the specific $\mathrm{AT}_{4}$ receptor antagonist, Divalinal-Ang IV, blocked this effect. ${ }^{126}$ Taken together, these results 
supported the hypothesis that Ang IV may act as a natriuretic agent via the ' $\mathrm{AT}_{4}$ receptor.' ${ }^{26}$ However, we did not confirm an $\mathrm{AT}_{4}$-mediated natriuretic response to Ang IV in rats, although we were able to document a natriuretic response to fenoldopam, which was used as a positive control. ${ }^{62,125}$

In both conscious dogs and in normal human beings, i.v. infusion of low-dose Ang IV during acute double blockade of the RAS did not modify blood pressure and sodium excretion and did not increase plasma aldosterone concentration. ${ }^{55,109}$

\section{ANGIOTENSIN-(1-7)}

Ang-(1-7) is generated directly from Ang II by ACE2, another isoform of ACE, or from Ang I, via Ang-(1-9), a pathway that utilizes both ACE2 and ACE. ${ }^{136}$ Ang-(1-7) may also be generated from Ang I by various protease enzymes, including neprilysin, thimet oligopeptidase and prolyl oligopeptidase (Figure 1). Ang-(1-7) has a shorter half-life than Ang II; it can be catabolized by ACE into the biologically inactive pentapeptide, Ang-(1-5), or by aminopeptidases into inactive fragments. ${ }^{100,137}$ The G-protein-coupled Mas receptor was reported to mediate some of the effects of Ang-(1-7). ${ }^{138}$ Alternatively, other effects of Ang-(1-7) appeared to be mediated by $\mathrm{AT}_{1}$ and $\mathrm{AT}_{2}$ receptors as they were inhibited by the $\mathrm{AT}_{1}$ and $\mathrm{AT}_{2}$ receptor-selective antagonists (Figure 2), ${ }^{139}$ although radioligand binding assays suggested that these were low-affinity interactions. ${ }^{140}$

Some studies suggest that Ang-(1-7) may have a hypotensive activity. ${ }^{139,141}$ Untreated essential hypertensive patients exhibited lower urinary concentrations of Ang-(1-7) than normotensive controls. ${ }^{141,142}$ Ang-(1-7) inhibited Ang II-induced pressor responses in SHR, an effect reduced by blockade of the Mas receptor, cyclooxygenase inhibition or NOS inhibition, suggesting a role for Mas receptor-mediated release of prostaglandins and $\mathrm{NO}$ in this blood pressure-lowering effect of Ang-(1-7). ${ }^{143}$ In conscious SHR treated with the $\mathrm{AT}_{1}$ receptor antagonist candesartan, Ang-(1-7) evoked a depressor response via activation of the $\mathrm{AT}_{2}$ receptor, involving the bradykinin-NO cascade. ${ }^{139,144}$ Hypertensive animals treated with ACE inhibitors had a 25- to 50-fold increase of circulating levels of Ang(1-7), suggesting that Ang-(1-7) might contribute to the antihypertensive effects produced by ACE inhibitors. ${ }^{145-147}$

The role of Ang-(1-7) in the regulation of kidney function is not well understood and conflicting data were reported. Some groups failed to detect effects of Ang-(1-7) on RBF in rats, ${ }^{145,148}$ but others observed a renal vasodilator response, and reported afferent arteriolar dilatation mediated by NO. ${ }^{149}$ In contrast, in isolated perfused hydronephrotic rat kidneys, Ang-(1-7) at high concentrations activated the $\mathrm{AT}_{1}$ receptor, thereby inducing renal microvascular constriction in small interlobular arteries, afferent arterioles and efferent arterioles. ${ }^{135}$

The data on the role of Ang-(1-7) in the regulation of salt and water excretion are also difficult to reconcile. In anesthetized rats, administration of Ang-(1-7) increased urinary flow rate and sodium excretion, an effect abolished by the Ang-(1-7) receptor antagonist A-779 (ref. 146). However, the increase in urinary sodium and water excretion after intrarenal infusion of Ang-(1-7) in dogs was reduced by $\mathrm{AT}_{1}$, but not $\mathrm{AT}_{2}$ receptor blockade, suggesting a role for Ang-(17)-mediated signaling via the $\mathrm{AT}_{1}$ receptor. ${ }^{150}$ In contrast, in waterloaded rats, infusion of Ang-(1-7) decreased urine volume, an effect reversed by Mas receptor blockade. ${ }^{140}$ In conscious dogs and in normal human beings, i.v. infusion of a low dose of Ang-(1-7) during acute double blockade of the RAS did not modify blood pressure and sodium excretion and did not increase plasma aldosterone concentration. ${ }^{5,109}$ Other studies in man have shown a slight pressor response after infusion of a higher dose of Ang-(1-7) in healthy volunteers, ${ }^{151}$ whereas infusion into the brachial artery of patients with heart failure treated with an ACE inhibitor did not induce significant forearm blood flow changes. ${ }^{152}$

In conclusion, Ang-(1-7) mediates its effects by binding to kidney Mas receptors, although some actions may occur via $\mathrm{AT}_{1}$ or $\mathrm{AT}_{2}$ receptors. The role of this peptide in the physiological and pathophysiological regulation of blood pressure and renal function awaits clarification.

\section{ANGIOTENSIN A}

Ang A, a newly discovered Ang-derived peptide, was detected in plasma of healthy human beings and, in increased concentrations, in patients with renal failure. ${ }^{8}$ In the presence of mononuclear leukocytes, Ang A appears to be generated from Ang II by enzymatic decarboxylation of $\mathrm{Asp}^{1}$ (ref. 8). Jankowski et al. ${ }^{8}$ claimed that Ang A is a partial agonist with the same affinity for the $\mathrm{AT}_{1}$ receptor as Ang II, but a higher affinity for the $\mathrm{AT}_{2}$ receptor (Figure 2). More recent in vitro binding studies of Ang $\mathrm{A}$ in $\mathrm{CHO}-\mathrm{hAT}_{1}$ and to $\mathrm{CHO}-\mathrm{AT}_{2}$ cells did not confirm this, and showed that Ang A has similar binding affinity for the $\mathrm{AT}_{1}$ receptors and the $\mathrm{AT}_{2}$ receptors as Ang II. The reason for this discrepancy may be due to the different experimental conditions. Moreover, in experiments with $\mathrm{AT}_{1}$-mediated IP accumulation, Ang A produced a similar maximal effect as Ang II, indicating that it is a full $\mathrm{AT}_{1}$ receptor agonist. ${ }^{153}$

Jankowski et al. ${ }^{8}$ also claimed that Ang A may modulate the harmful effects of Ang II because of more pronounced effects at the $\mathrm{AT}_{2}$ receptor. ${ }^{8}$ However, in the isolated perfused rat kidney, Ang A induced dose-dependent vasoconstriction, which was abolished by $\mathrm{AT}_{1}$ receptor blockade, but not by the $\mathrm{AT}_{2}$ receptor antagonist PD123319 (ref. 8). In the same line, Ang A induced, although with lower potency than Ang II, pressor and renal vasoconstrictor responses (with maximal responses of the same magnitude as Ang II) in normotensive rats and SHR, which were abolished by $\mathrm{AT}_{1}$ receptor blockade, but not modified by $\mathrm{AT}_{2}$ receptor blockade. ${ }^{153,154}$ Furthermore, by using transgenic mice, we showed that the $\mathrm{AT}_{1 \mathrm{a}}$ receptor subtype mediates these pressor and renal vascular effects of Ang A. No putative $\mathrm{AT}_{2}$ receptor-mediated vasodilator effects of Ang $\mathrm{A}$ were detected in normotensive rats, SHR and mice, and also not under conditions of $\mathrm{AT}_{1}$ receptor blockade. ${ }^{153}$

Overall, in contrast to earlier observations, Ang A is not a partial agonist with greater affinity for $\mathrm{AT}_{2}$ receptors than Ang II, but displays similar in vitro and in vivo properties as Ang II. This is in line with the hypothesis that the N-terminal aspartate residue of Ang II does not play an important function in binding to and stimulating these receptors. ${ }^{99,155}$ There are no published data on the effects of Ang A on sodium handling and aldosterone secretion nor on effects in human beings, but based on the above findings, it can be speculated that exogenous Ang A administration would produce effects similar to Ang II.

A well-validated nano-liquid chromatography-tandem mass spectrometry method, ${ }^{156}$ which has limits of quantification for Ang fragments in the low pM range, failed to detect Ang A in the plasma of rats, suggesting that the endogenous plasma levels of Ang A in rats are very low compared with plasma concentrations of Ang II. This is in line with the reportedly lower plasma concentrations of Ang A vs. Ang II in healthy subjects and end-stage renal failure patients. ${ }^{8}$

\section{CONCLUSION}

Ang II, the main effector peptide of the RAS, increases arterial pressure through arterioral vasoconstriction and by decreasing renal salt and 
water excretion through extrarenal and intrarenal mechanisms. Both effects are largely mediated through stimulation of $\mathrm{AT}_{1}$ receptors, resulting in renal cortical vasoconstriction (but vasodilation of the medullary vessels) and sodium reabsorption. The inhibition of these deleterious $\mathrm{AT}_{1}$ receptor-mediated effects through $\mathrm{ACE}$ inhibitors or Ang receptor blockers (and more recently the direct renin inhibitor aliskiren) largely explains as to why the two former classes of antihypertensive drugs have become the 'gold standard' of antihypertensive therapy. ${ }^{157}$

Although it is generally assumed that $\mathrm{AT}_{2}$ receptors oppose the responses mediated by $\mathrm{AT}_{1}$ receptors, and therefore may attenuate the pressor effects of Ang II, a possible role of $\mathrm{AT}_{2}$ receptors in the regulation of renal hemodynamics and sodium homeostasis remains to be unclear. The recent availability of Compound 21, the first orally active selective $\mathrm{AT}_{2}$ receptor agonist, opens the possibility to explore whether $\mathrm{AT}_{2}$ receptor stimulation could be a valuable concept for an innovative antihypertensive therapy. ${ }^{56,158,159}$ However, so far controversial results have been reported regarding its effect on blood pressure, depending on the species and the experimental conditions, and it is therefore difficult to predict the effects of long-term $\mathrm{AT}_{2}$ receptor stimulation in human beings. ${ }^{159}$ The current knowledge does rather suggest that $\mathrm{AT}_{2}$ receptor stimulation will not become another antihypertensive strategy. However, there appears to be other more immediate indications for the clinical drug development of Compound 21, such as heart failure, nephroprotection, stroke and antiinflammation. ${ }^{158}$ Nevertheless, the availability of this new selective compound will certainly help to better understand the physiological and pathophysiological role of the $\mathrm{AT}_{2}$ receptor, and the complex interactions between the two Ang receptor subtypes.

Ang III also increases blood pressure and reduces RBF through activation of $\mathrm{AT}_{1}$ receptors, but is more rapidly cleared from the plasma than Ang II. Ang III may be a relatively more important regulator of renal hemodynamics and sodium homeostasis in SHR. The observation that Ang III is more potent than Ang II in stimulating aldosterone secretion may suggest the possibility of the existence of a specific receptor for Ang III, which, however, awaits identification.

Ang IV has $\mathrm{AT}_{1}$ receptor-dependent pressor renal vasoconstrictor effects, but with lower potency than Ang II. The possibility of a role of the IRAP/AT ${ }_{4}$ receptor in the regulation of renal hemodynamics and renal sodium handling suggested by earlier reports has not been confirmed by more recent research. Current evidence does not suggest that this peptide plays a significant role in the control of blood pressure or renal function.

Ang-(1-7) may have a hypotensive activity through interaction with the Mas receptor, resulting in prostaglandin and NO release. Studies on the possible role of this peptide in the regulation of renal hemodynamics and sodium excretion have yielded conflicting results. Overall, the currently available evidence does not suggest that this peptide plays a major role in the regulation of blood pressure and renal function, although it may act as a modulator of Ang II-mediated effects under certain conditions.

Studies on the effects of Ang A, a recently discovered novel human Ang-derived peptide, where only the N-terminal amino acid is different from Ang II, have also yielded conflicting results. One group of investigators suggested a role for Ang A as a naturally occurring peptide counteracting the Ang II-mediated vasoconstrictor effects via a predominant $\mathrm{AT}_{2}$ receptor-mediated effect. This was, however, not confirmed by more recent research, indicating that Ang A displays similar in vitro and in vivo properties as Ang II. These findings, together with the very low plasma concentrations of Ang A, do not provide evidence for a physiological role of Ang
A as a naturally occurring peptide, possibly counteracting the Ang II-mediated vasoconstrictor effects.

\section{CONFLICT OF INTEREST}

The authors declare no conflict of interest.

\section{ACKNOWLEDGEMENTS}

This research was supported by a grant from the Research council of the Vrije Universiteit Brussel.

1 Skeggs LT, Lentz KE, Gould AB, Hochstrasser H, Kahn JR. Biochemistry and kinetics of the renin-angiotensin system. Fed Proc 1967; 26: 42-47.

2 Phillips MI, Speakman EA, Kimura B. Levels of angiotensin and molecular biology of the tissue renin-angiotensin systems. Regul Pept 1993; 43: 1-20.

3 Dorer FE, Kahn JR, Lentz KE, Levine M, Skeggs LT. Purification and properties of angiotensin-converting enzyme from hog lung. Circ Res 1972; 31: 356-366.

4 Ardaillou R, Chansel D, Chatziantoniou C, Dussaule JC. Biology and functions of renal receptors for angiotensin II and its active fragments. Adv Nephrol Necker Hosp 1998; 28: 225-257.

5 Chansel D, Ardaillou R. Active metabolites derived from angiotensin II. Nephrologie 1998; 19: 427-432.

6 Mustafa T, Lee JH, Chai SY, Albiston AL, McDowall SG, Mendelsohn FA. Bioactive angiotensin peptides: focus on angiotensin IV. J Renin-Angiotensin-Aldosterone Syst 2001; 2: 205-210.

7 Ferrario CM, Chappell MC, Tallant EA, Brosnihan KB, Diz DI. Counterregulatory actions of angiotensin-(1-7). Hypertension 1997; 30: 535-541.

8 Jankowski V, Vanholder R, van der GM, Tolle M, Karadogan S, Gobom J, Furkert J, Oksche A, Krause E, Tran TN, Tepel M, Schuchardt M, Schluter H, Wiedon A, Beyermann M, Bader M, Todiras M, Zidek W, Jankowski J. Mass-spectrometric identification of a novel angiotensin peptide in human plasma. Arterioscler Thromb Vasc Biol 2007; 27: 297-302.

9 Paul M, Poyan MA, Kreutz R. Physiology of local renin-angiotensin systems. Physiol Rev 2006; 86: 747-803.

10 van Kats JP, Schalekamp MA, Verdouw PD, Duncker DJ, Danser AH. Intrarenal angiotensin II: interstitial and cellular levels and site of production. Kidney Int 2001; 60: 2311-2317.

11 Danser AH, Admiraal PJ, Derkx FH, Schalekamp MA. Angiotensin I-to-II conversion in the human renal vascular bed. J Hypertens 1998; 16: 2051-2056.

12 Seikaly MG, Arant Jr BS, Seney Jr FD. Endogenous angiotensin concentrations in specific intrarenal fluid compartments of the rat. J Clin Invest 1990; 86: 1352-1357.

13 Timmermans PB, Wong PC, Chiu AT, Herblin WF, Benfield P, Carini DJ, Lee RJ, Wexler RR, Saye JA, Smith RD. Angiotensin II receptors and angiotensin II receptor antagonists. Pharmacol Rev 1993; 45: 205-251.

14 de Gasparo M, Catt KJ, Inagami T, Wright JW, Unger T. International union of pharmacology. XXIII. The angiotensin II receptors. Pharmacol Rev 2000; 52: 415-472.

15 Steckelings UM, Kaschina E, Unger T. The AT2 receptor-a matter of love and hate. Peptides 2005; 26: 1401-1409.

16 Harding JW, Wright JW, Swanson GN, Hanesworth JM, Krebs LT. AT4 receptors: specificity and distribution. Kidney Int 1994; 46: 1510-1512.

17 Handa RK, Krebs LT, Harding JW, Handa SE. Angiotensin IV AT4-receptor system in the rat kidney. Am J Physiol 1998; 274: F290-F299.

18 Burns KD. Angiotensin II and its receptors in the diabetic kidney. Am J Kidney Dis 2000; 36: 449-467.

19 Miserey S, Clauser E. Angiotensin II receptors: classification, structure, and signal transduction. Therapie 1998; 53: 205-211.

20 Llorens-Cortes C, Greenberg B, Huang H, Corvol P. Tissular expression and regulation of type 1 angiotensin II receptor subtypes by quantitative reverse transcriptasepolymerase chain reaction analysis. Hypertension 1994; 2: 538-548.

21 Burson JM, Aguilera G, Gross KW, Sigmund CD. Differential expression of angiotensin receptor $1 \mathrm{~A}$ and $1 \mathrm{~B}$ in mouse. Am J Physiol 1994; 267: E260-E267.

22 Miyata N, Park F, Li XF, Cowley Jr AW. Distribution of angiotensin AT1 and AT2 receptor subtypes in the rat kidney. Am J Physiol 1999; 277: F437-F446.

23 Grone HJ, Simon M, Fuchs E. Autoradiographic characterization of angiotensin receptor subtypes in fetal and adult human kidney. Am J Physiol 1992; 262: F326-F331.

24 Tsutsumi K, Saavedra JM. Characterization and development of angiotensin II receptor subtypes (AT1 and AT2) in rat brain. Am J Physiol 1991; 261: R209-R216.

25 Viswanathan M, Tsutsumi K, Correa FM, Saavedra JM. Changes in expression of angiotensin receptor subtypes in the rat aorta during development. Biochem Biophys Res Commun 1991; 179: 1361-1367.

26 Goto M, Mukoyama M, Suga S, Matsumoto T, Nakagawa M, Ishibashi R, Kasahara M, Sugawara A, Tanaka I, Nakao K. Growth-dependent induction of angiotensin II type 2 receptor in rat mesangial cells. Hypertension 1997; 30: 358-362.

27 Ozono R, Wang ZQ, Moore AF, Inagami T, Siragy HM, Carey RM. Expression of the subtype 2 angiotensin (AT2) receptor protein in rat kidney. Hypertension 1997; 30: 1238-1246. 
28 Zhuo J, Dean R, MacGregor D, Alcorn D, Mendelsohn FA. Presence of angiotensin II AT2 receptor binding sites in the adventitia of human kidney vasculature. Clin Exp Pharmacol Physiol Supp/ 1996; 3: S147-S154.

29 Ruiz-Ortega M, Esteban V, Suzuki Y, Ruperez M, Mezzano S, Ardiles L, Justo P, Ortiz A, Egido J. Renal expression of angiotensin type 2 (AT2) receptors during kidney damage. Kidney Int Suppl 2003; 86: S21-S26.

30 Hakam AC, Hussain T. Renal angiotensin II type-2 receptors are upregulated and mediate the candesartan-induced natriuresis/diuresis in obese Zucker rats. Hypertension 2005; 45: 270-275.

31 Otsuka S, Sugano M, Makino N, Sawada S, Hata T, Niho Y. Interaction of mRNAs for angiotensin II type 1 and type 2 receptors to vascular remodeling in spontaneously hypertensive rats. Hypertension 1998; 32: 467-472.

32 Zhu YZ, Chimon GN, Zhu YC, Lu Q, Li B, Hu HZ, Yap EH, Lee HS, Wong PT. Expression of angiotensin II AT2 receptor in the acute phase of stroke in rats. Neuroreport 2000; 11: 1191-1194.

33 Steckelings UM, Wollschlager T, Peters J, Henz BM, Hermes B, Artuc M. Human skin: source of and target organ for angiotensin II. Exp Dermatol 2004; 13: 148-154.

34 Steckelings UM, Henz BM, Wiehstutz S, Unger T, Artuc M. Differential expression angiotensin receptors in human cutaneous wound healing. Br J Dermatol 2005; 153: 887-893.

35 Batenburg WW, Garrelds IM, Bernasconi CC, Juillerat-Jeanneret L, van Kats JP, Saxena PR, Danser AH. Angiotensin II type 2 receptor-mediated vasodilation in human coronary microarteries. Circulation 2004; 109: 2296-2301.

36 Matsubara H, Sugaya T, Murasawa S, Nozawa Y, Mori Y, Masaki H, Maruyama K, Tsutumi Y, Shibasaki Y, Moriguchi Y, Tanaka Y, Isawaka T, Inada M. Tissue-specific expression of human angiotensin $\mathrm{II} \mathrm{AT}_{1}$ and $\mathrm{AT}_{2}$ receptors and cellular localization of subtype mRNAs in adult human renal cortex using in situ hybridization. Nephron 1998; 80: 25-34.

37 Ingert C, Grima M, Coquard C, Barthelmebs M, Imbs JL. Contribution of angiotensin II internalization to intrarenal angiotensin II levels in rats. Am J Physiol Renal Physio 2002; 283: F1003-F1010.

38 Guyton AC (ed). Human Physiology and Mechanisms of Disease, 5th edn. WB Saunders: Philadelphia, PA, 1992, 157pp.

39 Lumbers ER. Angiotensin and aldosterone. Regul pept 1999; 80: 91-100.

40 Hall JE. Control of sodium excretion by angiotensin II: intrarenal mechanisms and blood pressure regulation. Am J Physiol 1986; 250(6, Part 2): R960-R972.

41 Daniels D, Yee DK, Fluharty SJ. Angiotensin II receptor signaling. Exp Physiol 2007; 92: 523-527.

42 Badzynska B, Grzelec-Mojzesowicz M, Dobrowolski L, Sadowski J. Differential effect of angiotensin II on blood circulation in the renal medulla and cortex of anaesthetised rats. J Physiol 2002; 538: 159-166.

43 Champion HC, Czapla MA, Kadowitz PJ. Responses to angiotensin peptides are mediated by AT1 receptors in the rat. Am J Physiol 1998; 274: E115-E123.

44 Li XC, Campbell DJ, Ohishi M, Yuan S, Zhuo JL. AT1 receptor-activated signaling mediates angiotensin IV-induced renal cortical vasoconstriction in rats. Am J Physio Renal Physiol 2006; 290: F1024-F1033.

45 Rudenstam J, Creutz J, Gothberg G, Karlstrom G, Bergstrom G. Regional renal haemodynamics of angiotensin II infusion under prostaglandin, kinin or converting enzyme inhibition in the Wistar rat. Blood Press 2000; 9: 169-175.

46 Gembardt F, Heringer-Walther S, van Esch JH, Sterner-Kock A, van VR, Le TH, Garrelds IM, Coffman TM, Danser AH, Schultheiss HP, Walther T. Cardiovascular phenotype of mice lacking all three subtypes of angiotensin II receptors. FASEB $J$ 2008; 22: 3068-3077.

47 Yang R, Walther T, Gembardt F, Smolders I, Vanderheyden P, Albiston AL, Chai SY, Dupont AG. Renal vasoconstrictor and pressor responses to angiotensin IV in mice are AT1a-receptor mediated. J Hypertens 2010; 28: 487-494.

48 Ito M, Oliverio MI, Mannon PJ, Best CF, Maeda N, Smithies O, Coffman TM. Regulation of blood pressure by the type $1 \mathrm{~A}$ angiotensin II receptor gene. Proc Natl Acad Sci USA 1995; 92: 3521-3525.

49 Sugaya T, Nishimatsu S, Tanimoto K, Takimoto E, Yamagishi T, Imamura K, Goto S, Imaizumi K, Hisada Y, Otsuka A. Angiotensin II type 1a receptordeficient mice with hypotension and hyperreninemia. J Biol Chem 1995; 270: 18719-18722.

50 Chen X, Li W, Yoshida H, Tsuchida S, Nishimura H, Takemoto F, Okubo S, Fogo A, Matsusaka T, Ichikawa I. Targeting deletion of angiotensin type 1B receptor gene in the mouse. Am J Physiol 1997; 272: F299-F304.

51 Oliverio MI, Best CF, Kim HS, Arendshorst WJ, Smithies O, Coffman TM. Angiotensin II responses in AT1A receptor-deficient mice: a role for AT1B receptors in blood pressure regulation. Am J Physiol 1997; 272: F515-F520.

52 Tsuchida S, Matsusaka T, Chen X, Okubo S, Niimura F, Nishimura H, Fogo A, Utsunomiya $\mathrm{H}$, Inagami T, Ichikawa I. Murine double nullizygotes of the angiotensin type $1 \mathrm{~A}$ and $1 \mathrm{~B}$ receptor genes duplicate severe abnormal phenotypes of angiotensinogen nullizygotes. J Clin Invest 1998; 101: 755-760.

53 Shanmugam S, Sandberg K. Ontogeny of angiotensin II receptors. Cell Biol Int 1996; 20: $169-176$

54 Crowley SD, Gurley SB, Herrera MJ, Ruiz P, Griffiths R, Kumar AP, Kim HS, Smithies $O$, Le TH, Coffman TM. Angiotensin II causes hypertension and cardiac hypertrophy through its receptors in the kidney. Proc Natl Acad Sci USA 2006; 103: 17985-17990.

55 Plovsing RR, Wamberg CH, Sandgaard NCF, Simonsen JA, Holstein-Rathlou N-H, Høilund-Carlsen PF, Bie P. Effects of truncated angiotensins in humans after double blockade of the renin system. Am J Physiol Regul Integr Comp Physiol 2003; 285: R981-R991.
56 Paulis L, Unger T. Novel therapeutic targets for hypertension. Nat Rev Cardiol 2010; 7: 431-441.

57 Huang WC. Renal hemodynamic and tubular effects of angiotensins II and III. Chin J Physiol 1991; 34: 121-138.

58 Vyas SJ, Jackson EK. Angiotensin II: enhanced renal responsiveness in young genetically hypertensive rats. J Pharmacol Exp Ther 1995; 273: 768-777.

59 Handa RK. Biphasic actions of angiotensin IV on renal blood flow in the rat. Regul Pept 2006; 136: 23-29.

60 Coleman JKM, Krebs LT, Hamilton TA, Ong B, Lawrence KA, Sardinia MF, Harding JW, Wright JW. Autoradiographic identification of kidney angiotensin IV binding sites and angiotensin IV-induced renal cortical blood flow changes in rats. Peptides 1998; 19 : 269-277.

61 Clayton JS, Clark KL, Johns EJ, Drew GM. Effects of prostaglandins and nitric oxide on the renal effects of angiotensin II in the anaesthetized rat. Br J Pharmacol 1998; 124: 1467-1474.

62 Yang R, Smolders I, De BD, Fouyn R, Halberg M, Demaegdt H, Vanderheyden P, Dupont AG. Brain and peripheral angiotensin II type 1 receptors mediate renal vasoconstrictor and blood pressure responses to angiotensin IV in the rat. $J$ Hypertens 2008; 26: 998-1007.

63 Arendshorst WJ, Brannstrom K, Ruan X. Actions of angiotensin II on the renal microvasculature. J Am Soc Nephrol 1999; 10: S149-S161.

64 Yamamoto T, Hayashi K, Matsuda H, Kubota E, Tanaka H, Ogasawara Y, Nakamoto H, Suzuki $\mathrm{H}$, Saruta T, Kajiya F. In vivo visualization of angiotensin II- and tubuloglomerular feedback-mediated renal vasoconstriction. Kidney Int 2001; 60: 364-369.

65 Olsen ME, Hall JE, Montani JP, Guyton AC, Langford HG, Cornell JE. Mechanisms of angiotensin II natriuresis and antinatriuresis. Am J Physiol 1985; 249: F299-F307.

66 Bie P, Wamberg S, Kjolby M. Volume natriuresis vs. pressure natriuresis. Acta Physiol Scand 2004; 181: 495-503.

67 Granger JP, Alexander BT, Llinas M. Mechanisms of pressure natriuresis. Curr Hypertens Rep 2002; 4: 152-159.

68 Navar LG, Paul RV, Carmines PK, Chou CL, Marsh DJ. Intrarenal mechanisms mediating pressure natriuresis: role of angiotensin and prostaglandins. Fed Proc 1986; 45: 2885-2891.

69 Zhao D, Navar LG. Acute angiotensin II infusions elicit pressure natriuresis in mice and reduce distal fractional sodium reabsorption. Hypertension 2008; 52: 137-142.

70 Harris PJ. Stimulation of proximal tubular sodium reabsorption by ile5 angiotensin II in the rat kidney. Pflugers Arch 1979; 381: 83-85.

71 Houillier P, Chambrey R, Achard JM, Froissart M, Poggioli J, Paillard M. Signaling pathways in the biphasic effect of angiotensin II on apical $\mathrm{Na} / \mathrm{H}$ antiport activity in proximal tubule. Kidney Int 1996; 50: 1496-1505.

72 Ploth DW, Navar LG. Intrarenal effects of the renin-angiotensin system. Fed Proc 1979; 38: 2280-2285

73 Reilly AM, Harris PJ, Williams DA. Biphasic effect of angiotensin II on intracellular sodium concentration in rat proximal tubules. Am J Physiol 1995; 269. F374-F380.

74 Burns KD, Li N. The role of angiotensin II-stimulated renal tubular transport in hypertension. Curr Hypertens Rep 2003; 5: 165-171.

75 Hein L, Barsh GS, Pratt RE, Dzau VJ, Kobilka BK. Behavioural and cardiovascular effects of disrupting the angiotensin II type-2 receptor in mice. Nature 1995; 377: 744-777

76 Ichiki T, Labosky PA, Shiota C, Okuyama S, Imagawa Y, Fogo A, Niimura F, Ichikawa I, Hogan BL, Inagami T. Effects on blood pressure and exploratory behaviour of mice lacking angiotensin II type-2 receptor. Nature 1995; 377: 748-750.

77 Carey RM, Wang ZQ, Siragy HM. Role of the angiotensin type 2 receptor in the regulation of blood pressure and renal function. Hypertension 2000; 35: 155-163.

78 Goto M, Mukoyama M, Sugawara A, Suganami T, Kasahara M, Yahata K, Makino H, Suga S, Tanaka I, Nakao K. Expression and role of angiotensin II type 2 receptor in the kidney and mesangial cells of spontaneously hypertensive rats. Hypertens Res 2002; 25: $125-133$.

79 Carey RM, Padia SH. Angiotensin AT2 receptors: control of renal sodium excretion and blood pressure. Trends Endocrinol Metab 2008; 19: 84-87.

80 Savoia C, Touyz RM, Volpe M, Schiffrin EL. Angiotensin type 2 receptor in resistance arteries of type 2 diabetic hypertensive patients. Hypertension 2007; 49: 341-346.

81 Siragy HM, Carey RM. The subtype 2 angiotensin receptor regulates renal prostaglandin F-2 alpha formation in conscious rats. Am J Physiol 1997; 42: R1103-R1107.

82 Siragy HM, Inagami T, Ichiki T, Carey RM. Sustained hypersensitivity to angiotensin II and its mechanism in mice lacking the subtype-2 (AT2) angiotensin receptor. Proc Natl Acad Sci USA 1999; 96: 6506-6510.

83 Siragy HM, Senbonmatsu T, Ichiki T, Inagami T, Carey RM. Increased renal vasodilator prostanoids prevent hypertension in mice lacking the angiotensin subtype-2 receptor. J Clin Invest 1999; 104: 181-188.

84 Tanaka M, Tsuchida S, Imai T, Fujii N, Miyazaki H, Ichiki T, Naruse M, Inagami T. Vascular response to angiotensin II is exaggerated through an upregulation of AT1 receptor in AT2 knockout mice. Biochem Biophys Res Commun 1999; 258: 194-198.

85 Inagami T, Eguchi S, Numaguchi K, Motley ED, Tang H, Matsumoto T, Yamakawa T. Cross-talk between angiotensin II receptors and the tyrosine kinases and phosphatases. J Am Soc Nephrol 1999; 10: S57-S61.

86 Carey RM, Howell NL, Jin XH, Siragy HM. Angiotensin type 2 receptor-mediated hypotension in angiotensin type-1 receptor-blocked rats. Hypertension 2001; 38: 1272-1277.

87 Li XC, Widdop RE. AT2 receptor-mediated vasodilatation is unmasked by AT1 receptor blockade in conscious SHR. Br J Pharmacol 2004; 142: 821-830. 
88 Wan $Y$, Wallinder C, Plouffe B, Beaudry $H$, Mahalingam AK, Wu X, Johansson B, Holm M, Botoros M, Karlen A, Pettersson A, Nyberg F, Fandriks L, Gallo-Payet N, Hallberg A, Alterman M. Design, synthesis, and biological evaluation of the first selective nonpeptide AT2 receptor agonist. J Med Chem 2004; 47: 5995-6008.

89 Bosnyak S, Welungoda IK, Hallberg A, Alterman M, Widdop RE, Jones ES. Stimulation of angiotensin AT2 receptors by the non-peptide agonist, Compound 21, evokes vasodepressor effects in conscious spontaneously hypertensive rats. $\mathrm{Br} \mathrm{J}$ Pharmacol 2010; 159: 709-716.

90 Haithcock D, Jiao H, Cui XL, Hopfer U, Douglas JG. Renal proximal tubular AT2 receptor: signaling and transport. J Am Soc Nephrol 1999; 10: S69-S74.

91 Gross V, Schunck WH, Honeck H, Milia AF, Kargel E, Walther T, Bader M, Inagami T, Schneider W, Luft FC. Inhibition of pressure natriuresis in mice lacking the AT2 receptor. Kidney Int 2000; 57: 191-202.

92 Padia SH, Howell NL, Siragy HM, Carey RM. Renal angiotensin type 2 receptors mediate natriuresis via angiotensin III in the angiotensin II type 1 receptor-blocked rat. Hypertension 2006; 47: 537-544.

93 Rajapakse NW, Oliver JJ, Evans RG. Nitric oxide in responses of regional kidney blood flow to vasoactive agents in anesthetized rabbits. J Cardiovasc Pharmacol 2002; 40: 210-219.

94 Bergstrom G, Evans RG. Mechanisms underlying the antihypertensive functions of the renal medulla. Acta Physiol Scand 2004; 181: 475-486.

95 Sarkis A, Liu KL, Lo M, Benzoni D. Angiotensin II and renal medullary blood flow in Lyon rats. Am J Physiol Renal Physiol 2003; 284: F365-F372.

96 Liu KL. Regulation of renal medullary circulation by the renin-angiotensin system in genetically hypertensive rats. Clin Exp Pharmacol Physiol 2009; 36: 455-461.

97 Reaux A, Fournie-Zaluski MC, Llorens-Cortes C. Angiotensin III: a central regulator of vasopressin release and blood pressure. Trends Endocrinol Metab 2001; 12: 157-162.

98 Zini S, Fournie-Zaluski MC, Chauvel E, Roques BP, Corvol P, Llorens-Cortes C. Identification of metabolic pathways of brain angiotensin II and III using specific aminopeptidase inhibitors: predominant role of angiotensin III in the control of vasopressin release. Proc Natl Acad Sci USA 1996; 93: 11968-11973.

99 Le MT, Vanderheyden PM, Szaszak M, Hunyady L, Vauquelin G. Angiotensin IV is a potent agonist for constitutive active human AT1 receptors. Distinct roles of the $\mathrm{N}$ - and C-terminal residues of angiotensin II during AT 1 receptor activation. J Biol Chem 2002; 277: 23107-23110.

100 Cesari M, Rossi GP, Pessina AC. Biological properties of the angiotensin peptides other than angiotensin II: implications for hypertension and cardiovascular diseases. J Hypertens 2002; 20: 793-799.

101 Nobes MS, Harris PJ, Yamada H, Mendelsohn FAO. Effects of angiotensin on renal cortical and papillary blood flows measured by Laser-Doppler flowmetry. Am J Physiol 1991; 261: F998-F1006.

102 Gammelgaard I, Wamberg S, Bie P. Systemic effects of angiotensin III in conscious dogs during acute double blockade of the renin-angiotensin-aldosterone-system. Acta Physiol (Oxf) 2006; 188: 129-138.

103 Mustafa MR, Dharmani M, Kunheen NK, Sim MK. Effects of des-aspartateangiotensin I on the actions of angiotensin III in the renal and mesenteric vasculature of normo- and hypertensive rats. Regul Pept 2004; 120: 15-22.

104 Healy DP, Song L. Kidney aminopeptidase A and hypertension, part I: spontaneously hypertensive rats. Hypertension 1999; 33: 740-745.

105 Padia SH, Kemp BA, Howell NL, Siragy HM, Fournie-Zaluski MC, Roques BP, Carey RM. Intrarenal aminopeptidase $\mathrm{N}$ inhibition augments natriuretic responses to angiotensin III in angiotensin type 1 receptor-blocked rats. Hypertension 2007; 49: 625-630.

106 Harris PJ, Munro JO. Reversal by angiotensins II and III of the effects of converting enzyme inhibition on renal electrolyte excretion in rats. J Physiol 1984; 351: 491-500.

107 Britton SL, Fiksen-Olsen MJ, Houck PC, Romero JC. Intrarenal vascular effects of angiotensin II and angiotensin III in the dog. Hypertension 1983; 1: 95-101.

108 Freeman RH, Davis JO, Khosla MC. Renal and adrenal responses to [des.Asp[1]1] angiotensin I in the dog. Am J Physiol Renal Fluid Electrolyte Physiol 1987; 234: F130-F134.

109 Wamberg CH, Plovsing RR, Sandgaard NCF, Bie P. Effects of different angiotensins during acute, double blockade of the renin system in conscious dogs. Am J Physiol Regul Integr Comp Physiol 2003; 285: R971-R980.

110 Ardaillou R, Chansel D. Synthesis and effects of active fragments of angiotensin II. Kidney Int 1997; 52: 1458-1468.

111 Chansel D, Czekalski S, Vandermeersch S, Ruffet E, Fournie-Zaluski MC, Ardaillou R. Characterization of angiotensin IV-degrading enzymes and receptors on rat mesangial cells. Am J Physiol 1998; 275: F535-F542.

112 Chansel D, Vandermeersch S, Oko A, Curat C, Ardaillou R. Effects of angiotensin IV and angiotensin-(1-7) on basal and angiotensin II-stimulated cytosolic $\mathrm{Ca}^{2+}$ in mesangial cells. Eur J Pharmacol 2001; 414: 165-175.

113 Chen JK, Zimpelmann J, Harris RC, Burns KD. Angiotensin IV induces tyrosine phosphorylation of focal adhesion kinase and paxillin in proximal tubule cells. $\mathrm{Am} \mathrm{J}$ Physiol-Renal Physiol 2001; 280: F980-F988.

114 Reaux A, Fournie-Zaluski MC, David C, Zini S, Roques BP, Corvol P, Llorens-Cortes C. Aminopeptidase A inhibitors as potential central antihypertensive agents. Proc Nat Acad Sci USA 1999; 96: 13415-13420.

115 Handa RK, Harding JW, Simasko SM. Characterization and function of the bovine kidney epithelial angiotensin receptor subtype 4 using angiotensin IV and divalinal angiotensin IV as receptor ligands. J Pharmacol Exp Ther 1999; 291: 1242-1249.
116 Swanson GN, Hanesworth JM, Sardinia MF, Coleman JKM, Wright JW, Hall KL, Millerwing AV, Stobb JW, Cook VI, Harding EC, Harding JW. Discovery of a distinct binding-site for angiotensin-II (3-8), a putative angiotensin-IV receptor. Regul Pept 1992; 40: 409-419.

117 Zhang JH, Hanesworth JM, Sardinia MF, Alt JA, Wright JW, Harding JW. Structural analysis of angiotensin IV receptor (AT4) from selected bovine tissues. J Pharmacol Exp Ther 1999; 289: 1075-1783.

118 Albiston AL, McDowall SG, Matsacos D, Sim P, Clune E, Mustafa T, Lee J, Mendelsohn FA, Simpson RJ, Connolly LM, Chai SY. Evidence that the angiotensin IV (AT(4)) receptor is the enzyme insulin-regulated aminopeptidase. J Biol Chem 2001; 276: $48623-48626$.

119 Dulin N, Madhun ZT, Chang CH, Berti-Mattera L, Dickens D, Douglas JG. Angiotensin IV receptors and signaling in opossum kidney cells. Am J Physiol 1995; 269: F644-F652.

120 Garreau I, Chansel D, Vandermeersch S, Fruitier I, Piot JM, Ardaillou R. Hemorphins inhibit angiotensin IV binding and interact with aminopeptidase N. Peptides 1998; 19: 1339-1348.

121 Czekalski S, Chansel D, Vandermeersch S, Ronco P, Ardaillou R. Evidence for angiotensin IV receptors in human collecting duct cells. Kidney Int 1996; 50: $1125-1131$.

122 Handa RK. Characterization and signaling of the AT(4) receptor in human proximal tubule epithelial (HK-2) cells. J Am Soc Nephrol 2001; 12: 440-449.

123 Millerwing AV, Hanesworth JM, Sardinia MF, Hall KL, Wright JW, Speth RC, Grove KL, Harding JW. Central angiotensin-IV binding-sites-distribution and specificity in Guinea-Pig brain. J Pharmacol Exp Ther 1993; 266: 1718-1726.

124 Chai SY, Bastias MA, Clune EF, Matsacos DJ, Mustafa T, Lee JH, McDowall SG, Paxinos G, Mendelsohn FA, Albiston AL. Distribution of angiotensin IV binding sites (AT4 receptor) in the human forebrain, midbrain and pons as visualised by in vitro receptor autoradiography. J Chem Neuroanat 2000; 20: 339-348.

125 Dupont AG, Yang R, Smolders I, Vanderheyden P. IRAP and AT(1) receptor mediated effects of angiotensin IV. J Intern Med 2009; 265: 401-403.

126 Hamilton TA, Handa RK, Harding JW, Wright JW. A role for the angiotensin IV/AT(4) system in mediating natriuresis in the rat. Peptides 2001; 22: 935-944.

127 Patel JM, Martens JR, Li YD, Gelband CH, Raizada MK, Block ER. Angiotensin IV receptor-mediated activation of lung endothelial NOS is associated with vasorelaxation. Am J Physiol 1998; 275: L1061-L1068.

128 Patel JM, Li YD, Zhang J, Gelband CH, Raizada MK, Block ER. Increased expression of calreticulin is linked to ANG IV-mediated activation of lung endothelial NOS. Am J Physiol 1999; 277: L794-L801.

129 Kramar EA, Krishnan R, Harding JW, Wright JW. Role of nitric oxide in angiotensin IV-induced increases in cerebral blood flow. Regul Pept 1998; 74: 185-192.

130 Yoshida M, Kikukawa M, Hisa H, Satoh S. Modulation by nitric oxide and prostaglandin of the renal vascular response to angiotensin II (3-8). Br J Pharmacol 1996; 117 : 885-890.

131 Gardiner SM, Kemp PA, March JE, Bennett T. Regional haemodynamic effects of angiotensin II (3-8) in conscious rats. Br J Pharmacol 1993; 110: 159-162.

132 Fitzgerald SM, Evans RG, Bergstrom G, Anderson WP. Renal hemodynamic responses to intrarenal infusion of ligands for the putative angiotensin IV receptor in anesthetized rats. J Cardiovasc Pharmacol 1999; 34: 206-211.

133 Demaegdt H, Vanderheyden P, De Backer JP, Mosselmans S, Laeremans H, Le MT, Kersemans V, Michotte Y, Vauquelin G. Endogenous cystinyl aminopeptidase in Chinese hamster ovary cells: characterization by [125I]Ang IV binding and catalytic activity. Biochem Pharmacol 2004; 68: 885-892.

134 Dworkin LD, Brenner BM. The renal circulation. In Brenner BM, Rector FC Jr (eds). The Kidney. WB Saunder: Philadelphia, PA, 1991, p 164.

135 van Rodijnen WF, van Lambalgen TA, van Wijhe MH, Tangelder GJ, Ter Wee PM. Renal microvascular actions of angiotensin II fragments. Am J Physiol Renal Physiol 2002; 283: F86-F92.

136 Donoghue M, Hsieh F, Baronas E, Godbout K, Gosselin M, Stagliano N, Donovan M, Woolf B, Robison K, Jeyaseelan R, Breitbart RE, Acton S. A novel angiotensinconverting enzyme-related carboxypeptidase (ACE2) converts angiotensin I to angiotensin 1-9. Circ Res 2000; 87: E1-E9.

137 Chappell MC, Pirro NT, Sykes A, Ferrario CM. Metabolism of angiotensin(1-7) by angiotensin converting enzyme. Hypertension 1998; 31: 362-367.

138 Santos RA, Simoes e Silva AC, Maric C, Silva DM, Machado RP, de BI, Heringer-Walther S, Pinheiro SV, Lopes MT, Bader M, Mendes EP, Lemos VS, Campagnole-Santos MJ, Schultheiss HP, Speth R, Walther T. Angiotensin-(1-7) is an endogenous ligand for the G protein-coupled receptor Mas. Proc Natl Acad Sci USA 2003; 100: 8258-8263.

139 Walters PE, Gaspari TA, Widdop RE. Angiotensin-(1-7) acts as a vasodepressor agent via angiotensin II type 2 receptors in conscious rats. Hypertension 2005; 45 : 960-966.

140 Santos RA, Simoes e Silva AC, Magaldi AJ, Khosla MC, Cesar KR, Passaglio KT, Baracho NC. Evidence for a physiological role of angiotensin-(1-7) in the control of hydroelectrolyte balance. Hypertension 1996; 27: 875-884.

141 Sampaio WO, Nascimento AAS, Santos RAS. Regulation of cardiovascular signaling by kinins and products of similar converting enzyme systems - systemic and regional hemodynamic effects of angiotensin-(1-7) in rats. Am J Physiol Heart Circ Physiol 2003; 284: H1985-H1994.

142 Ferrario CM, Martell N, Yunis C, Flack JM, Chappell MC, Brosnihan KB, Dean RH, Fernandez A, Novikov SV, Pinillas C, Luque M. Characterization of angiotensin-(1-7) in the urine of normal and essential hypertensive subjects. Am J Hypertens 1998; 11: 137-146. 
143 Dharmani M, Mustafa MR, Achike FI, Sim MK. Effects of angiotensin 1-7 on the actions of angiotensin II in the renal and mesenteric vasculature of hypertensive and streptozotocin-induced diabetic rats. Eur J Pharmacol 2007; 561: $144-150$.

144 Kohara K, Brosnihan KB, Ferrario CM. Angiotensin(1-7) in the spontaneously hypertensive rat. Peptides 1993; 14: 883-891.

145 van der Wouden EA, Ochodnicky P, van Dokkum RPE, Roks AJM, Deelman LE, de Zeeuw D, Henning $\mathrm{RH}$. The role of angiotensin(1-7) in renal vasculature of the rat. J Hypertens 2006; 24: 1971-1978.

146 Handa RK, Ferrario CM, Strandhoy JW. Renal actions of angiotensin-(1-7): in vivo and in vitro studies. Am J Physiol 1996; 270: F141-F147.

147 Campbell DJ, Kladis A, Duncan AM. Effects of converting enzyme inhibitors on angiotensin and bradykinin peptides. Hypertension 1994; 23: 439-449.

148 SimoeseSilva AC, Baracho NCV, Passaglio KT, Santos RAS. Renal actions of angiotensin-(1-7). Braz J Med Biol Res 1997; 30: 503-513.

149 Ren YL, Garvin JL, Carretero OA. Vasodilator action of angiotensin-(1-7) on isolated rabbit afferent arterioles. Hypertension 2002; 39: 799-802.

150 Heller J, Kramer HJ, Maly J, Cervenka L, Horacek V. Effect of intrarenal infusion of angiotensin-(1-7) in the dog. Kidney Blood Press Res 2000; 23: 89-94.

151 Kono T, Taniguchi A, Imura H, Oseko F, Khosla MC. Biological activities of angiotensin II(1-6) hexapeptide and angiotensin II(1-7) heptapeptide in man. Life Sci 1986; 38 1515-1519.

152 Davie AP, McMurray JJ. Effect of angiotensin(1-7) and bradykinin in patients with heart failure treated with an ACE inhibitor. Hypertension 1999; 34: 457-460.
153 Yang R, Gembardt F, Walther T, Lukaszuk A, Tourwe D, Vanderheyden P, Smolders I, Dupont AG. Pressor and renal effects of angiotensin A [abstract]. J Hypertens 2009; 27: S453.

154 Badejo Jr A, Greco AJ, Casey DB, Cook JL, Murthy SN, Kadowitz PJ. Analysis of hemodynamic responses and the proliferative effect of the novel angiotensin peptide Angiotensin A. Abstract. http://www.fasebj.org/cgi/content/meeting_abstract/ 23/1_MeetingAbstracts/935.2; data accessed 4 March 2011.

155 Capponi AM, Catt KJ. Angiotensin II receptors in adrenal cortex and uterus. Binding and activation properties of angiotensin analogues. J Biol Chem 1979; 254: 5120-5127.

156 Lanckmans K, Stragier B, Sarre S, Smolders I, Michotte Y. Nano-LC-MS/MS for the monitoring of angiotensin IV in rat brain microdialysates: limitations and possibilities. J Sep Sci 2007; 30: 2217-2224.

157 Mancia G, De Backer G, Dominiczak A, Cifkova R, Fagard R, Germano G, Grassi G, Heagerty AM, Kjeldsen SE, Laurent S, Narkiewicz K, Ruilope L, Rynkiewicz A, Schmieder RE, Struijker Boudier HA, Zanchetti A. Guidelines for the management of arterial hypertension: the task force for the management of arterial hypertension of the European Society of Hypertension (ESH) and of the European Society of Cardiology (ESC). J Hypertens 2007; 25: 1105-1187.

158 Unger T, Dahlöf B. Compound 21, the first orally active, selective agonist of the angiotensin type 2 receptor $\left(\mathrm{AT}_{2}\right)$ : implications for $\mathrm{AT}_{2}$ receptor research and therapeutic potential. J Renin 2010; 11: 75-77.

159 Lemarié CA, Schiffrin EL. The angiotensin II type 2 receptor in cardiovascular disease. J Renin 2010; 11: 19-31. 